\section{Dietary effects of oregano (Origanum vulgaris L.) plant or sweet chestnut (Castanea sativa Mill.) wood extracts on microbiological, chemico-physical characteristics and lipid oxidation of cooked ham during storage}

\author{
David Ranucci, ${ }^{1}$ Dino Miraglia, ${ }^{1}$ \\ Massimo Trabalza-Marinucci, ${ }^{1}$ \\ Gabriele Acuti, ${ }^{1}$ Michela Codini, ${ }^{2}$ \\ Maria Rachele Ceccarini, ${ }^{2}$ Claudio Forte, ${ }^{1}$ \\ Raffaella Branciari' \\ 'Department of Veterinary Medicine, \\ University of Perugia, Perugia; \\ 'Department of Pharmaceutical Sciences, \\ University of Perugia, Perugia, Italy
}

\section{Abstract}

The aim of this study was to evaluate the dietary effect of feeding pigs with diets enriched with sweet chestnut wood (Castanea sativa Mill.) or oregano (Origanum vulgaris L.) extract on the microbiological and chemical characteristics of cooked pork ham. Three groups of 10 pigs were fed with a control diet (CTRL), with the CTRL diet enriched with $0.2 \%$ of oregano extract (OR) and with the CTRL diet enriched with $0.2 \%$ of sweet chestnut wood extract (SCW), respectively. Six cooked hams per group were produced, sliced and packaged under a modified atmosphere $(\mathrm{N} 2: \mathrm{CO} 2=80: 20)$ and stored at refrigeration temperature $\left(4 \pm 1^{\circ} \mathrm{C}\right)$. Three packages per cooked ham were sampled for analyses at three different storage times (0, 10 and 20 days). At day 0 time, antioxidant capacity of the products $\left(\mathrm{ORAC}_{\mathrm{FL}}\right.$ assay) and chemical composition were performed. At each sampling time, from all the samples the following analyses were performed: total microbial count (TMC), lactic acid bacteria count (LAB), Enterobacteriaceae count, Listeria monocytogenes, $\mathrm{pH}$ value, colour coordinates $\left(\mathrm{L}^{*}, \mathrm{a}^{*}, \mathrm{~b}^{*}\right)$, total basic volatile nitrogen (TBVN) and thiobarbituric reactive substances (TBARs) determinations. No differences in TMC, LAB and Enterobacteriaceae count, $\mathrm{pH}$, TBVN, chemical composition and $\mathrm{L}^{*}$ values were registered between the three groups at all the sampling times considered. No Listeria monocytogenes was detected in the samples tested. Significant differences were registered for $\mathrm{ORAC}_{\mathrm{FL}}$ at 0 days, $\mathrm{a}^{*}$ and $\mathrm{b}^{*}$ values and TBARs value at 10 and 20 days of storage, with higher values for
$\operatorname{ORAC}_{\mathrm{FL}}, \mathrm{a}^{*}$ and $\mathrm{b}^{*}$ values and lower values for TBARs in SCW and OR than CTRL. No antimicrobial effect could be recorded for $\mathrm{OR}$ and SCW but a higher oxidative stability, also highlighted by the colour maintenance, was observed in both OR and SCW.

\section{Introduction}

Antimicrobial and antioxidant activity of different natural plant extracts is well documented (Zheng and Wang, 2001; Burt, 2004; Bozin et al., 2006). Recently, the effects of dietary supplementation with natural bioactive compounds on food quality have been considered (Branciari et al., 2015). The main effect recorded is a reduction in lipid oxidation in meat (Simitzis et al., 2008; Lauchky et al., 2010; Ranucci et al., 2015) and meat products (Ranucci et al., 2013), but the effect on the meat hygiene was also reported (Nieto et al., 2010).

A high content of bioactive polyphenolic compounds is present in sweet chestnut (Castanea sativa Mill.) wood extract (SCWE) and oregano (Origanum vulgaris L) extract (Barreira et al., 2008; Comandini et al., 2014). For this reason, the use of these extracts in animal feed has been proposed for its positive effects on growth performance and meat quality traits (Schiavone et al., 2008; Liu et al., 2009). Both oregano and SCWE are considered also for their antioxidant property (SanchezEscalante et al., 2003; Frankic and Solobir, 2011), as polyphenols owed both radical scavenging and iron binding activities (Lopes $e t$ al., 1999). Furthermore, the in vitro antimicrobial effects of both extracts are reported. Oregano extract was proved effective against Listeria monocytogenes, Bacillus cereus, Staphylococcus aureus and Escherichia coli (Shan et al., 2007). SCWE affects the main pathogens responsible for enteric disorders in different poultry (broilers, turkeys, layer hens), cattle and swine productions (Graziani et al., 2006). For oregano, dietary administration shows an inhibitory effect of oregano leaves on the turkey breast fillet microbial load (Botsoglu et al., 2010).

No data is yet available, on the effects of the dietary enrichment with oregano extract or SCWE on the microbial, oxidative and quality characteristics of the pork meat products. The aim of the present work is to evaluate the effects of a diet enriched in oregano extract or SCWE on the hygienic characteristics, oxidative stability and some quality traits of cooked pork ham during storage.
Correspondence: David Ranucci, Department of Veterinary Medicine, University of Perugia, via San Costanzo 4, 06126 Perugia (PG), Italy Tel: +39.075.5857931 - Fax: +39.075 .5857928 .

E-mail: david.ranucci@unipg.it

Key words: Natural storage; Cooked ham; Antioxidant.

Conflict of interest: the authors declare no potential conflict of interest.

Received for publication: 25 August 2015. Revision received: 1 October 2015

Accepted for publication: 1 October 2015 .

This work is licensed under a Creative Commons Attribution-NonCommercial 3.0 International License (CC BY-NC 3.0).

(C) Copyright D. Ranucci et al., 2015

Licensee PAGEPress, Italy

Italian Journal of Food Safety 2015; 4:5497

doi:10.4081/ijfs.2015.5497

\section{Materials and Methods}

This study was conducted from July to October 2014 on a small farm in Umbria, Italy. Thirty Italian Large White $\mathrm{x}$ Landrace $\mathrm{x}$ Duroc crossbred male/female hybrid pigs, with an average live weight (LW) of $108.1 \pm 11.1 \mathrm{~kg}$ at the beginning of the trial, were divided into 3 groups (10 animals/group) and balanced for the LW and sex. The diets (crude protein: $15.86 \%$, ether extract: $4.01 \%$, crude fibre: $5.08 \%)$ were isonitrogenous and isoenergetic: i) control (CTRL), a commercial pelleted diet; ii) OR, the CTRL diet with the addition of $0.2 \%$ oregano extract; iii) SCW, the CTRL diet with the addition of $0.2 \%$ sweet chestnut wood extract. After 68 days of the trial, the animals (final LW: $153.5 \pm 12.9 \mathrm{~kg}$ ) were slaughtered in a local abattoir and submitted to a local meat product industry for the cooked hams production. Carcasses were deboned after refrigeration and cooked hams were produced from each group according to the food producer's procedures. In particular neither ascorbic acid as an antioxidant nor nitrites as preservatives were used. In addition, no final pasteurisation was performed on the products. Six cooked hams/group were aseptically sliced after refrigeration and packaged under a modified atmosphere condition ( $\mathrm{N} 2: \mathrm{CO} 2=80: 20$; multilayer film composed by polypropylene-ethylene vinil alcohol-polypropylene; Tecknofood Pack, Castelnovetto, PV, Italy) in $150 \mathrm{~g}$ serving packs. Nine packs for each cooked ham were sampled for chemical-physical and microbiological analyses. The analyses were performed at 3 hours on 0 day of storage ( 3 packs/ham/group), at 10 days of storage (3 packs/ham/group) and 20 
days of storage (3 packs/ham/group). Storage was performed at $4 \pm 1^{\circ} \mathrm{C}$.

After 3 hour (0 day of storage) from packaging the following measurements were performed: chemical composition (AOAC, 1990); oxygen radical absorbance capacity assay $\left(\mathrm{ORAC}_{\mathrm{FL}}\right)$ as described by Branciari et al. (2015); pH determination as described by Bendal (1975); colour coordinates (CIE, 1986), total volatile basic nitrogen (TVBN) as described by Pearson (1991); TBARs as described by Tarladgis et al. (1960).

The microbiological analyses were: total microbial count (TMC) on Plate Count Agar (PCA; Oxoid Ltd., Basingstoke, UK) aerobically incubated at $30^{\circ} \mathrm{C}$ for $72 \mathrm{~h}$; Lactobacillus spp. on MRS agar (Oxoid Ltd.) anaerobically incubated at $37^{\circ} \mathrm{C}$ for 48 h (LAB); Enterobacteriaceae count using Violet Red Bile Glucose Agar (VRBG; 0xoid Ltd.) aerobically incubated at $37^{\circ} \mathrm{C}$ for $24 \mathrm{~h}$. The results were normalized to colony forming unit (cfu) $\mathrm{g}^{-1}$ and converted into Log values. The presence of Listeria monocytogenes was also tested for using the criteria set by ISO 11290-1 (ISO, 1996).

The determination of $\mathrm{pH}$, colour, TVBN and TBARs, and the microbial analyses were repeated at 10 and 20 days of storage at $4^{\circ} \mathrm{C}$.

Data were analyzed using an ANOVA model (Statview; SAS Institute inc., Cary, NC, USA) with diet and time as fix factors. For chemical composition and $\mathrm{ORAC}_{\mathrm{FL}}$ only diet were considered as fixed factor. Tukey's test was used for post hoc comparisons between groups. Differences were considered to be significant when $\mathrm{P}<0.05$. For microbial analysis the dietary effects on the same sampling time was evaluated using the unpaired T test (Statview) and the significance level was set at a value of $\mathrm{P}<0.05$.

\section{Results}

The chemical composition and $\mathrm{ORAC}_{\mathrm{FL}}$ values of the products are reported in Figures 1 and 2 . No differences were recorded for chemical composition between the groups. Higher $\mathrm{ORAC}_{\mathrm{FL}}$ mean values were recorded in SCW (14.20 0.69 standard deviation) and $\mathrm{OR}$ $(13.03 \pm 1.03)$ than CTRL $(9.95 \pm 0.96)$ group $(\mathrm{P}<0.001)$.

Microbiological analyses ( $n=18$ for each group at each sampling time) show an increase in TMC and LAB values during storage (Figure 3). No differences were recorded among CTRL, OR and SCW groups at the same storage times considered. Enterobacteriaceae counts were below the detection limit in all the samples tested (with an exception in one SCW sample at 10 days of storage with $\log 2.3 \mathrm{cfu} \mathrm{g}^{-1}$ value). No Listeria monocytogens was isolated

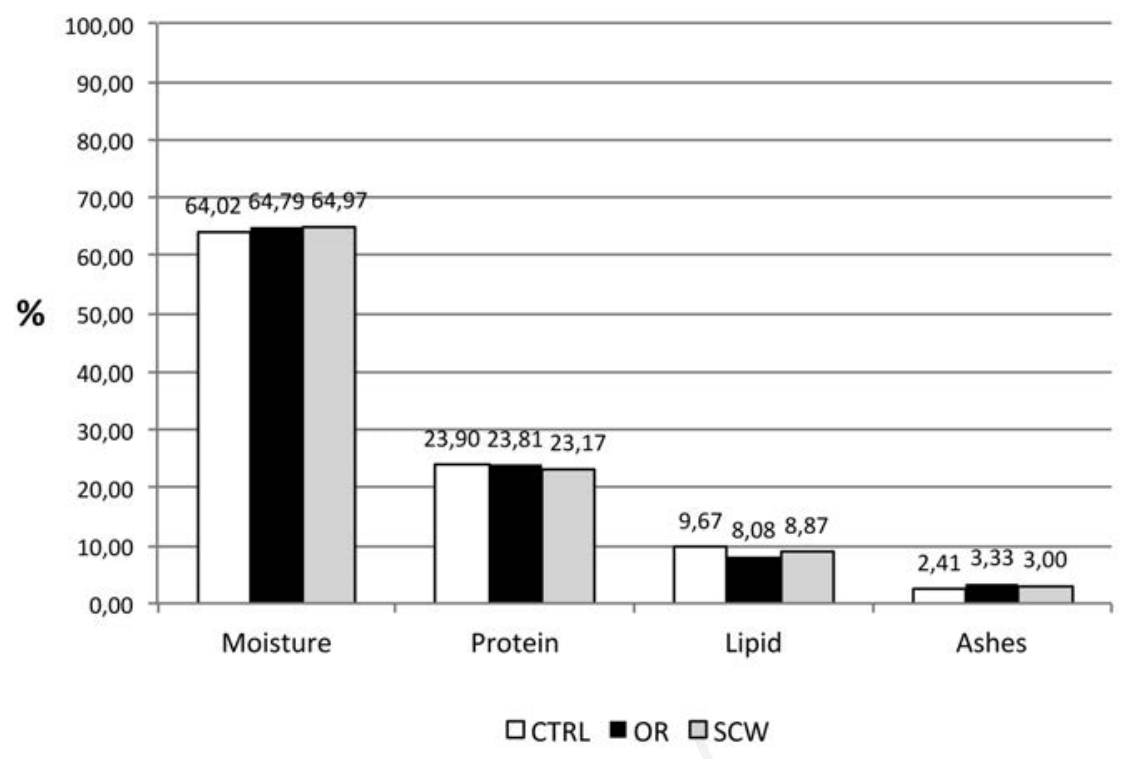

Figure 1. Chemical composition (\%) of cooked pork hams produced from pigs fed with oregano extract $(\mathrm{OR})$, with sweet chestnut wood extract $(\mathrm{SCW})$, and with a standard diet (CTRL) (n=6 hams/group).

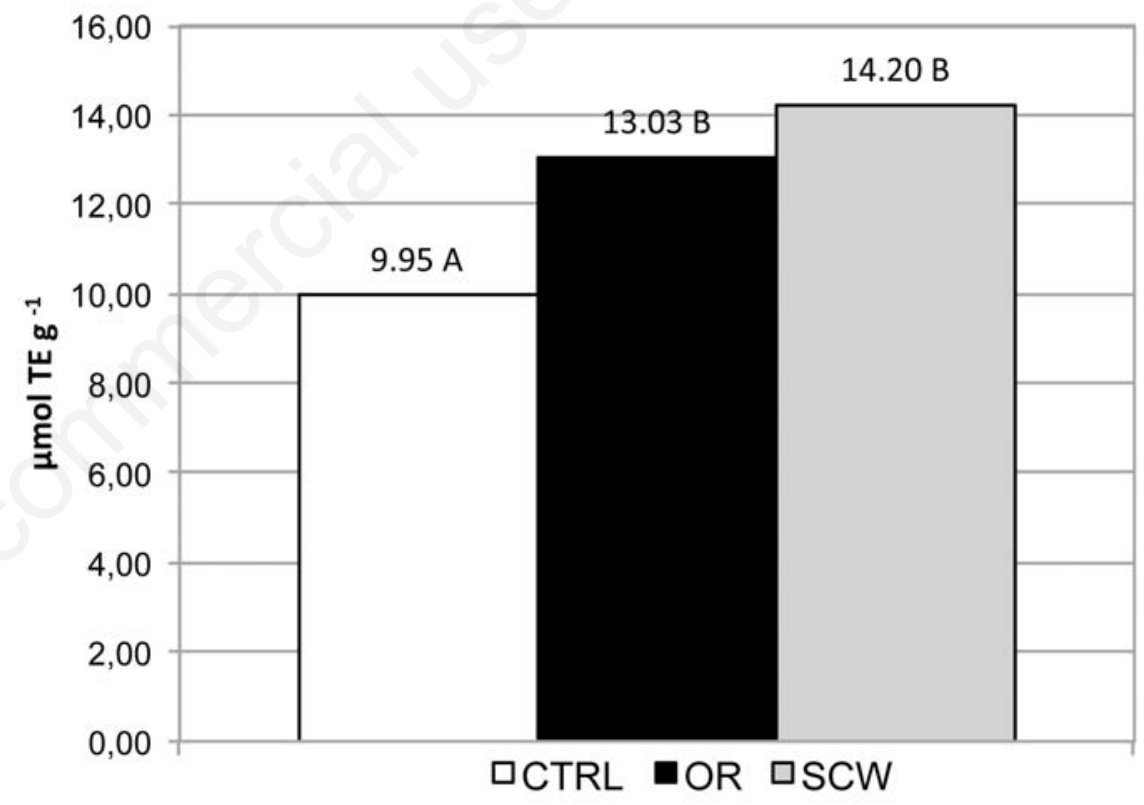

Figure 2. Antioxidant capacity of the products ( $\mu \mathrm{mol}$ Trolox $\bigodot$ equivalent $\mathrm{g}^{-1}$ ) of cooked pork hams produced from pigs fed with oregano extract (OR), with sweet chestnut wood extract $(\mathrm{SCW})$, and with a standard diet (CTRL) (n=6 hams/group). Different letters denote statistical differences $(\mathrm{P}<0.05)$.

from the samples.

For the physical-chemical analyses, $\mathrm{pH}, \mathrm{L}^{*}$ and TBVN values did not differ between the groups considered (Table 1). For ham redness ( $a^{*}$ value) and yellowishness ( $b^{*}$ value) no difference at 0 day of storage was registered between the groups but at 10 and 20 days of storage. Significant decreases were recorded only in CTRL samples ( $\mathrm{a}^{*}$ value: from 12.93 at 0 day to 9.65 at 20 days; for $b^{*}$ value from 8.51 at 0 days to 6.83 at 20 days). TBARs values followed the same trend as higher values were recorded in CTRL samples than in OR and SCW after 10 and 20 days of storage. At 20 days TBARs value in SCW were also lower than OR (1.95 vs 2.06 $\mathrm{mg} \mathrm{MDA} / \mathrm{kg}$ respectively). The effect of time was evident for all the parameters considered (Table 1). 
Table 1. $\mathrm{pH}$, colour coordinates, total basic volatile nitrogen and thio-barbituric reactive substances values of cooked pork ham produced from pigs fed with oregano extract, sweet chestnut wood extract and with a standard diet at 0,10 and 20 days of storage (n=6 hams/group).

\begin{tabular}{|c|c|c|c|c|c|c|c|c|c|c|c|c|c|}
\hline \multirow[t]{3}{*}{ Parameters } & \multicolumn{9}{|c|}{ Storage time } & \multirow[t]{3}{*}{ SEM } & \multicolumn{3}{|c|}{$\mathbf{P}$} \\
\hline & & 0 day & & & 10 days & & & 20 day: & & & & & \\
\hline & CTRL & OR & SCW & CTRL & OR & SCW & CTRL & OR & SCW & & D & $\mathrm{T}$ & $\mathrm{D} \times \mathrm{T}$ \\
\hline $\mathrm{pH}$ & $6.14^{c}$ & $6.16^{\mathrm{c}}$ & $6.02^{c}$ & $5.79^{\mathrm{b}}$ & $5.79^{\mathrm{b}}$ & $5.75^{b}$ & $5.35^{\mathrm{a}}$ & $5.39^{\mathrm{a}}$ & $5.46^{\mathrm{a}}$ & 0.041 & 0.493 & $<0.001$ & 0.066 \\
\hline $\mathrm{L}^{*}$ & $62.34^{\mathrm{a}}$ & $60.76^{\mathrm{a}}$ & $61.53^{\mathrm{a}}$ & $63.93^{\mathrm{ab}}$ & $65.49^{\mathrm{b}}$ & $66.61^{\mathrm{b}}$ & $64.84^{\mathrm{b}}$ & $66.05^{b}$ & $66.46^{\mathrm{b}}$ & 1.084 & 0.415 & $<0.001$ & 0.474 \\
\hline$a^{*}$ & $12.93^{c}$ & $13.20^{c}$ & $12.73^{c}$ & $10.63^{\mathrm{b}}$ & $12.01^{\mathrm{c}}$ & $12.48^{c}$ & $9.65^{\mathrm{a}}$ & $11.91^{\mathrm{bc}}$ & $12.38^{c}$ & 0.570 & 0.005 & 0.003 & 0.140 \\
\hline$b^{*}$ & $8.51^{\mathrm{b}}$ & $7.89^{\mathrm{ab}}$ & $7.69^{a b}$ & $6.92^{\mathrm{a}}$ & $7.77^{\mathrm{ab}}$ & $7.83^{\mathrm{ab}}$ & $6.83^{\mathrm{a}}$ & $7.27^{\mathrm{ab}}$ & $7.39^{\mathrm{ab}}$ & 0.271 & 0.527 & 0.001 & 0.019 \\
\hline TVBN (mg $\left.100 \mathrm{~g}^{-1}\right)$ & $25.65^{\mathrm{a}}$ & $23.37^{\mathrm{a}}$ & $23.62^{\mathrm{a}}$ & $26.53^{\mathrm{b}}$ & $26.96^{\mathrm{b}}$ & $27.29^{b}$ & $30.56^{c}$ & $30.60^{c}$ & $31.25^{\mathrm{c}}$ & 0.303 & 0.122 & $<0.001$ & 0.638 \\
\hline TBARs (mg MDA kg-1) & $1.48^{\mathrm{a}}$ & $1.46^{\mathrm{a}}$ & $1.37^{\mathrm{a}}$ & $1.80^{c}$ & $1.70^{c}$ & $1.56^{\mathrm{b}}$ & $2.12^{\mathrm{f}}$ & $2.06^{\mathrm{e}}$ & $1.95^{\mathrm{d}}$ & 0.034 & $<0.001$ & $<0.001$ & 0.437 \\
\hline
\end{tabular}

SEM, standard error of mean; CTRL, control diet; OR, oregano extract; SCW, sweet chestnut wood extract; D, diet effect; T, time effect; DxT, interaction diet and time effects; $\mathrm{L}^{*}$, lightness; $\mathrm{a}^{*}$, redness; $\mathrm{b}^{*}$, yellowness; TVBN, total basic volatile nitrogen; TBARs, thio-barbituric reactive substances; MDA, malondialdehyde. ${ }^{\text {a-IMeans }}$ within a row with different letters are statistically different.

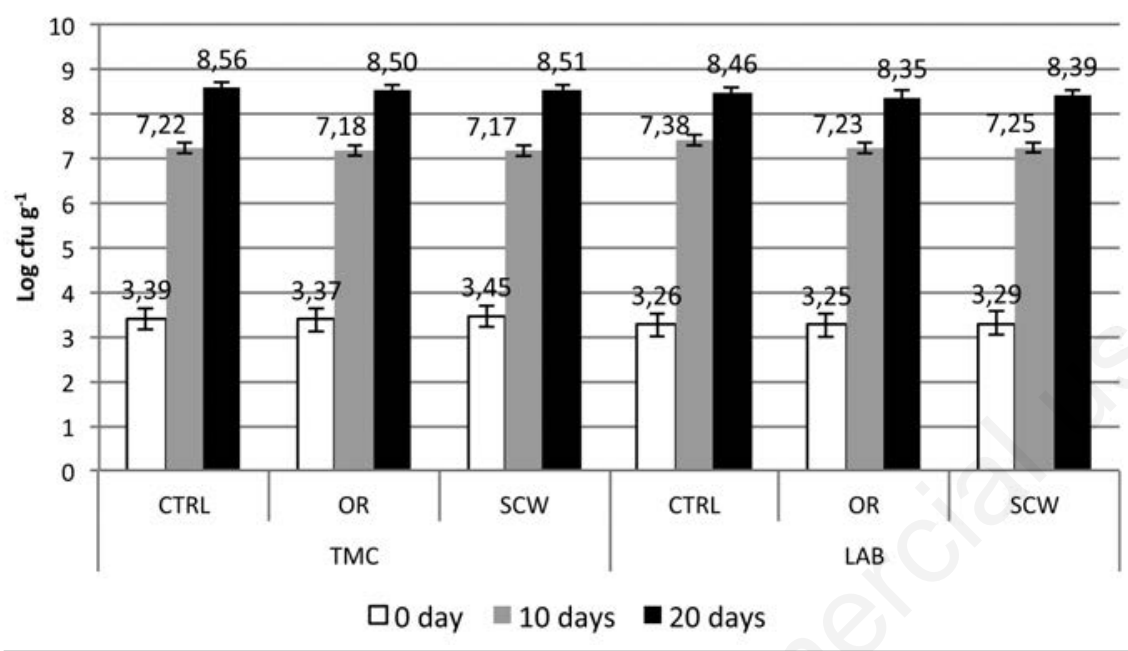

Figure 3. Total microbial count (TMC) and lactic acid bacteria count (LAB) (Log colony forming units $\mathrm{g}^{-1}$ ) evolution in cooked pork hams produced from pigs fed with oregano extract $(\mathrm{OR})$, with sweet chestnut wood extract $(\mathrm{SCW})$, with a standard diet at 0,10 and 20 days of storage (CTRL) (n= 6 hams/group).

\section{Discussion}

The $\mathrm{ORAC}_{\mathrm{FL}}$ results confirm that bioactive substances could reach meat and meat products through enriched diets (Moñino et al., 2008). These molecules are responsible for the different effects on the products but in this study only antioxidant effects were registered. Furthermore the hygienic characteristics of meat products are strongly affected by several factor including food processing, packaging and storage conditions. The addition of natural preservatives directly to the products could affect microbial growth only if a certain amount of extract is used (Zhang et al., 2009). Probably, in this study, the amount of bioactive substances used could not affect the hygienic characteristics of the products during storage. This consideration is in contrast to other author who found dietary antimicrobial effects of natural preservative in meat (Govaris et al.,
2007; Nieto et al., 2010; Bañón et al., 2012; Serrano et al., 2014), including oregano leaves (Botsoglou et al., 2010).

The dietary effects on lipid oxidation of $\mathrm{OR}$ and SCW was observed in cooked pork hams. This effects in meat exerted by oregano is reported by several authors (Simitzis et al., 2008), even though Janz et al. (2007) observed only a tendency towards a reduced lipid oxidation (oregano essential oil added to the diet at a dose of $0.05 \%$ ) and Simitzis et al. (2010) (feed supplemented with oregano essential oil at concentrations of $0.25,0.5$ and $1 \mathrm{ml} / \mathrm{kg}$ of fed diet) did not find any effect on stored pig meat when different concentrations of oregano essential oils were added to the diet. SCW extract was proved effective against lipid oxidation in rabbit meat (Liu et al., 2009) but not in poultry meat (Schiavone et al., 2008). An antioxidant effect of a combination of the two extract was found in pork meat when it was used in the diet of outdoor reared pigs
(Ranucci et al., 2015).

Oxidation is a relevant factor affecting shelf life of the products (i.e. development of offodour and off-flavour) (Nieto et al., 2011) and colour stability (Luciano et al., 2011). This effects was registered in SCW ham, where $\mathrm{a}^{*}$ value remained stable during storage time even when $\mathrm{pH}$ fell under acceptable conditions ( $\mathrm{pH}<5.5)$. The SCW samples showed a higher antioxidant capacity and subsequently a lower oxidation than $\mathrm{OR}$.

\section{Conclusions}

The dietary supplementation with SCWE and oregano extract affected the oxidative status of cooked pork ham but no antimicrobial effects were detected on the products. More relevant information could be provided by the evaluation of the antimicrobial effects on specific bacterial that inhabit the animal intestine and are responsible for foodborne disease and are possibly present in meat. Nonetheless the cooking process performed on the hams considered, that reach $72^{\circ} \mathrm{C}$ at the core of the product, is responsible for the elimination of such pathogens and only post process intervention (i.e. slicing) could contaminate the products. Strategies could nevertheless be considered with the use of such diet enrichments and other processing interventions able to promote food hygiene and improve shelf-life through a combination of antibacterial and antioxidant effects.

\section{References}

AOAC, 1990. Official methods of analysis. 15th ed. Association of Official Analytical Chemists ed., Washington, DC, USA.

Bañón S, Méndez L, Almela E, 2012. Effects of dietary rosemary extract on lamb spoilage 
under retail display conditions. Meat Sci 90:579-83.

Barreira JCM, Ferreira ICFR, Oliveira MBPP, Pereira JA, 2008. Antioxidant activities of the extracts from chestnut flower, leaf, skins and fruit. Food Chem 107:1106-13.

Bendal JR, 1975. Cold-contracture and atp-turnover in the red and white musculature of the pig, post mortem. J Sci Food Agr 26:5571.

Botsoglou E, Govaris A, Moulas A, Botsoglou N, 2010. Oxidative stability and microbial growth of turkey breast fillets during refrigerated storage as influenced by feed supplementation with olive leaves, oregano and/or $\alpha$-tocopheryl acetate. Brit Poultry Sci 51:760-8.

Bozin B, Mimika-Dukic N, Simin N, Anackov G, 2006. Characterization of the volatile composition of essential oils of some Lamiaceae spices and the antimicrobial and antioxidant activities of the entire oils. J Agr Food Chem 54:1822-8.

Branciari R, Ranucci D, Trabalza Marinucci M, Codini M, Orrù M, Ortenzi R, Forte C, Ceccarini MR, Valiani A, 2015. Evaluation of the antioxidant properties and oxidative stability of Pecorino cheese made from the raw milk of ewes fed Rosmarinus officinalis L. leaves. Int J Food Sci Tech 50:558-65.

Burt S, 2004. Essential oils: their antibacterial properties and potential applications in foods: a review. Int J Food Microbiol 94:223-53.

CIE, 1986. Colorimetry 15.2. Commission Internationale de l'Eclairage Publ., Vienna, Austria.

Comandini P, Lerma-Garcia MJ, Simó-Alfonzo EF, Toschi TG, 2014. Tannin analysis of chestnut bark samples (Castanea sativa Mill.) by HPLC-DAD-MS. Food Chem 157:290-5.

Frankic T, Solobir J, 2011. In vivo antioxidant potential of Sweet chestnut (Castanea sativa Mill.) wood extract in young growing pigs exposed to n-3 PUFA-induced oxidative stress. J Sci Food Agr 91:1432-9.

Govaris A, Florou-Paneri P, Botsoglou E, Giannenas I, Amvrosiadis I, Botsoglou N, 2007. The inhibitory potential of feed supplementation with rosemary and/or a-tocopheryl acetate on microbial growth and lipid oxidation of turkey breast during refrigerated storage. Food Sci Technol 40:331-7.

Graziani R, Tosi G, Denti R, 2006. In vitro antimicrobial activity of SILVA FEED ENC on bacterial strains of poultry origin. In: EPC
2006. Proceedings of the 12th European Poultry Conference, 10-14 September 2006, Verona, Italy.

ISO, 1996. Microbiology of food and animal feeding stuffs. Horizontal method for the detection and enumeration of Listeria monocytogenes. Part 1: Detection. ISO Norm 11290-1:1996. International Organisation for Standardization ed., Geneva, Switzerland.

Janz JAM, Morel PCH, Wilkinson BHP, Purchas RW, 2007. Preliminary investigation of the effects of low-level dietary inclusion of fragrant essential oils and oleoresins on pig performance and pork quality. Meat Sci 75:350-5.

Lahucky R, Nuernberg K, Kovac L, Bucko 0, Nuernberg G, 2010. Assessment of the antioxidant potential of selected plant extracts. In vitro and in vivo experiments on pork. Meat Sci 85:779-84.

Liu HW, Gai F, Gasco L, Brugiapaglia A, Lussiana C, Guo KJ, Tong JM, Zoccarato I, 2009. Effects of chestnut tannins on carcass characteristics, meat quality, lipid oxidation and fatty acid composition of rabbits. Meat Sci 83:678-83.

Lopes GK, Schulman HM, Hermes-Lima M, 1999. Polyphenol tannic acid inhibits hydroxyl radical formation from Fenton reaction by complexing ferrous ions. Biochim Biophys Acta 1472:142-52.

Luciano G, Vasta V, Monahan FJ, López-Andrés P, Biondi L, Lanza M, Priolo A, 2011. Antioxidant status, colour stability and myoglobin resistance to oxidation of longissimus dorsi muscle from lambs fed a tannin-containing diet. Food Chem 124:1036-42.

Moñino I, Martinez C, Sotomayor JA, Lafuente A, Jordan MJ, 2008. Polyphenolic transmission to Segureño lamb meat from ewes' diet supplemented with the distillate from rosemary (Rosmarinus officinalis) leaves. J Agr Food Chem 56:3363-7.

Nieto G, Diaz P, Bañón S, Garrido MD, 2010. Dietary administration of ewe diets with a distillate from rosemary leaves (Rosmarinus officinalis L.): influence on lamb meat quality. Meat Sci 84:23-9.

Nieto G, Estrada M, Jordan MJ, Garrido MD, Bañón S, 2011. Effects in ewe diet of rosemary by-product on lipid oxidation and the eating quality of cooked lamb under retail display conditions. Food Chem 124:1423-9.

Pearson D, 1991. The chemical analysis of food. University of Reading, Reading, UK.

Ranucci D, Beghelli D, Trabalza-Marinucci M,
Branciari R, Forte C, Olivieri 0, Badillo Pazmay GV, Cavallucci C, Acuti G, 2015. Dietary effects of a mix derived from oregano (Origanum vulgare L.) essential oil and sweet chestnut (Castanea sativa Mill.) wood extract on pig performance, oxidative status and pork quality traits. Meat Sci 100:319-26.

Ranucci D, Branciari R, Acuti G, Della Casa G, Trabalza Marinucci M, Miraglia D, 2013. Quality traits of Ciauscolo salami from meat of pigs fed rosemary extract enriched diet. Ital J Food Safety 2:49-52.

Sanchez-Escalante A, Djenane D, Torrescano G, Beltran JA, Roncales P, 2003. Antioxidant action of borage, rosemary, oregano, and ascorbic acid in beef patties packaged in modified atmosphere. J Food Sci 68:339-44.

Schiavone A, Guo K, Tassone S, Gasco L, Hernandez E, Denti R, Zoccarato I, 2008. Effects of a natural extract of chestnut wood on digestibility, performance traits, and nitrogen balance of broiler chicks. Poultry Sci 87:521-7.

Serrano R, Jordan MJ, Bañón S, 2014. Use of dietary rosemary extract in ewe and lamb to extendthe shelf life of raw and cooked meat. Small Ruminant Res 116:144-52.

Shan B, Kai Y-Z, Brooks JD, Corke H, 2007. The in vitro antibacterial activity of dietary spice and medicinal herb extracts. Int $\mathbf{J}$ Food Microbiol 117:112-9.

Simitzis PE, Deligeorgis SG, Bizelis JA, Dardamani A, Theodosiou I, Fegeros K, 2008. Effect of dietary oregano oil supplementation on lamb meat characteristics. Meat Sci 79:217-23.

Simitzis PE, Symeon GK, Charismiadou MA, Bizelis JA, Deligeorgis SG, 2010. The effects of dietary oregano oil supplementation on pig meat characteristics. Meat Sci 84:670-6.

Tarladgis BG, Watts BM, Yonathan M, 1960. Distillation method for the determination of malonaldehyde in rancid foods. J Am Oil Chem Soc 37:44-8.

Zhang H, Kong B, Xiong YL, Sun X, 2009. Antimicrobial activities of spice extracts against pathogenic and spoilage bacteria in modified atmosphere packaged fresh pork and vacuum packaged ham slices stored at $4^{\circ} \mathrm{C}$. Meat Sci 81:686-92.

Zheng W, Wang SY, 2001. Antioxidant activity and phenolic compounds in selected herbs. J Agr Food Chem 49:5165-70. 